\title{
Archaeological Site Recording
}

\author{
Zofia Kowarska and Szymon Lenarczyk with a contribution by Magdalena Antos
}

Archaeological research at the El-Zuma site was started in 2004/o5 (Mahmoud El-Tayeb 2005; Godlewski 2005). As part of the research project, the first contemporary geodetic survey of the site was carried out (using a theodolite) by Yassin Mohamed Saeed, mapping the cemetery together with the topography of the surrounding area (Mahmoud El-Tayeb 2005, 39o, Fig. 1) [Fig. 2.1]. Further geodetic work took place in 2007/o8, when the topographical map of the cemetery was modified using data from a Total Station survey conducted by Wiesław Małkowski (Mahmoud El-Tayeb 2010, 469, Fig. 2).

Detailed topographical recording, an inventory of all structures and completion of documentation from previous seasons was performed between 2014 and 2017. The data was collected using different, complementary, or overlapping information retrieval techniques. This work was carried out using surveying instruments (a Total Station) and photographic equipment (for aerial and traditional photography). A new architectural plan of the Early Makurian El-Zuma cemetery, complemented with previously missing data, was created, and a record was made of individual tumuli, including their cross-sections and, where possible, the dimensions of chambers, tunnels and shafts (see Chapter 3, in this volume).

Field documentation of particular archaeological sites within the Early Makuria Research Project, which, among others, included El-Zuma and El-Detti, was compiled in keeping with a scheme developed over several years (Mahmoud El-Tayeb et al. 2016).

An important operation aimed at protecting the ElZuma site was the construction of a perimeter fence. The site had been endangered by continuous degradation for many years, resulting from the frequent use of roads and paths that cut across it. The remains of many tumulus superstructures had been badly damaged by vehicle traffic. Additionally, the village of El-Zuma had been growing dynamically, though chaotically, for many years, and new houses had been erected ever closer to the archaeological site, or even within its boundaries.

The locations of the tumuli do not suggest that the cemetery was laid out according to a specific plan. All of the tumuli are located on higher ground between several water courses that run from the west towards the river. Apart from a cluster of more than ten tumuli identified in the central part of the site, a few single structures in its north-west and south-east parts can also be observed. It is notable that the largest mounds are located at the edges of the site, while the smaller ones are situated in the middle.

A review of written sources and earlier documentation formed an important part of the site recording process.

\section{Sources}

There are only a few mentions in written records about the area of today's El-Zuma site. The cemetery was described by 19th-century and early 2oth-century travellers, such as Karl Richard Lepsius and E.A. Wallis Budge (Lepsius 1852; Żurawski 2003, 45-46; Mahmoud El-Tayeb 2012, 18; Budge 1907, vol. I, 127, 129, 170; vol. II, 116; 1912, 866-867). Lepsius mentioned the areas neighbouring the modern-day village of El-Zuma, comparing the tumuli he saw in ElZuma to the pyramids from El-Kurru and Tanqasi. The map drawn by him is extremely detailed, and it constitutes an important cartographic source providing information about the state of the site in the 19th century (Lepsius 1852, 248-249) [Fig. 2.2]. Comparing the 19th-century map with the present state of the site reveals that the number of recognized tumuli has decreased. Some tumuli have been destroyed over the years by the growing village of El-Zuma. On his map, Lepsius marked structures, probably walls, surrounding some of the entrances to the tunnels on the south side of the tumuli.

None of the architectural elements mentioned by Lepsius have survived to this day. However, an analysis of particular tumuli marked on the aforesaid map suggests the existence of entrances leading directly to the tunnels and burial chambers of individual structures.

Lepsius also referred to the existence of El-Zuma fort (Karat Negil, known today as Karadegil or Galat Negil, which is part of El-Zuma Gubli; Żurawski 2002, 84; Lepsius $185^{2}, 248$ ); however, no trace of it can currently be found.

This is how Lepsius described his visit to El-Zuma:

Three quarters of an hour down the stream on the right, lies the little village of Zûma. Near it, towards the mountains, rises an old fortress, with towers of defence, called Kárat Négil, the outer walls of which 


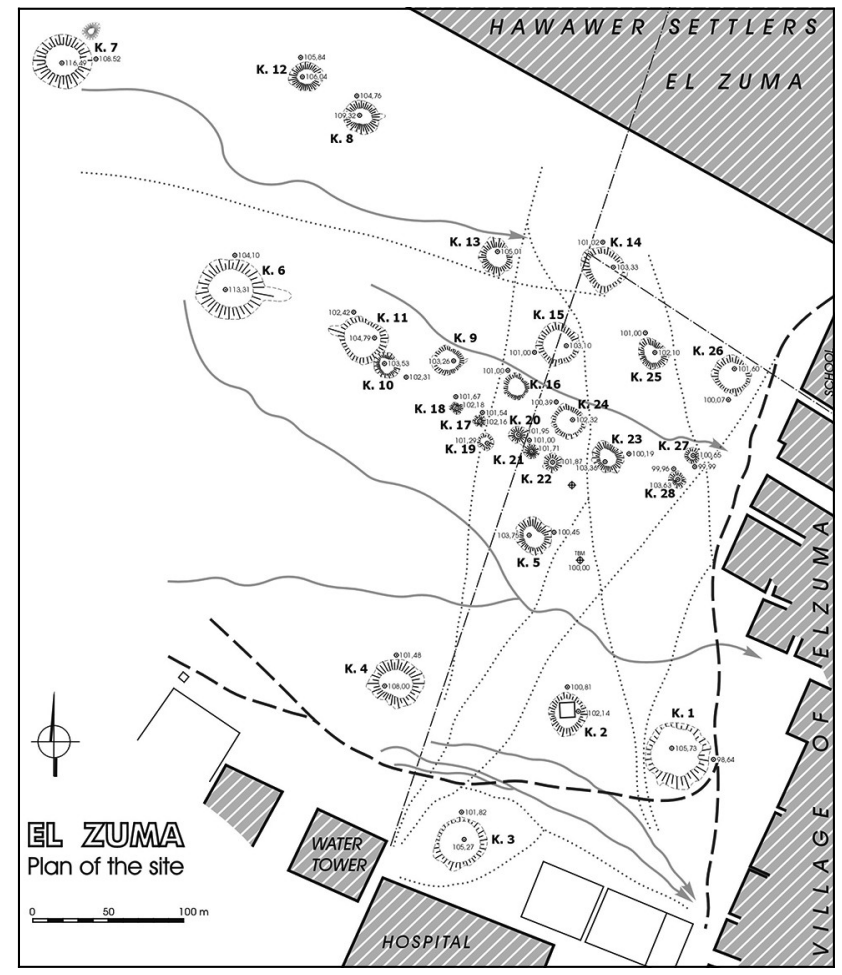

were ruined and destroyed about fifty or sixty years ago, when the present inhabitants of Zûma settled there. The name is derived from that of an old king of the country, called Négil, in whose time the surrounding land, which is now barren, was still reached and fertilized by the Nile.

The first discovery on the road to the fortress was another number of pyramids, of which eight were yet about twenty feet high; including the ruined ones, which seemed to have been as usual the most massive, there were altogether thirty; to the southwest the old quarries are yet to be seen, which had furnished the materials for the pyramids.

Whilst these three pyramid fields, Tangassi, Kurru, and Zûma, or Kárat Négil, lying so near to each other, and whose situation has been carefully paced off and marked by Erbkam, show that the neighbourhood had a numerous and flourishing population in the heathen times, we discovered in the adjoining country and more or less through the whole province of Dongala, the remains of Christian churches.

LEPSIUS 1852, 257-258

By superimposing an appropriately scaled version of Lepsius's $185^{2}$ plan onto a contemporary one drawn up during 2014-2015, it was possible to carry out a comparative analysis of the two [Fig. 2.3]. The details compared included the number and distribution of tumuli at the site and
FIGURE 2.1

Topographic plan of the cemetery in El-Zuma DRAWN BY YASSIN MOHAMED SAEED, DIGITISED BY M. PUSZKARSKI, AFTER MAHMOUD EL-TAYEB 2005, 39o, FIG. 1

the base diameter measurements of the individual superstructures [see Table 2.1]. There are evident differences between the plan of the cemetery recorded in the 19th century and the one produced by the recent survey in terms of the shapes, sizes, and outlines of the tumuli, as well as the distances between them. The discrepancies in the diameters of the same tumuli recorded using various methods in the 19th and 21st centuries are particularly obvious.

Despite these significant differences, Lepsius's plan is still an important and interesting historical source.

The base diameters of the same tumuli, as recorded in the 1850 s and in the early 200os, are listed alongside one another in Table 2.1. Most of the tumuli on Lepsius's plan have smaller base diameters than those on the modernday one. Seven of the tumuli on the 19th-century map are larger in diameter than they appear today, and in one case (T.27) the dimensions recorded on both plans are almost identical. These inconsistencies may stem from the use of different measurement techniques and different approaches to defining the maximum extent of the burial mounds. Their perimeters are only very faintly visible from the ground. Using modern recording methods, in particular kite aerial photography and the orthophoto map of the site produced by processing the images captured from the air, it was possible to roughly define the edges of the mounds. Another potential reason for the discrepancies in the recorded diameters of the tumuli is that these dimensions may have changed over the years. The 


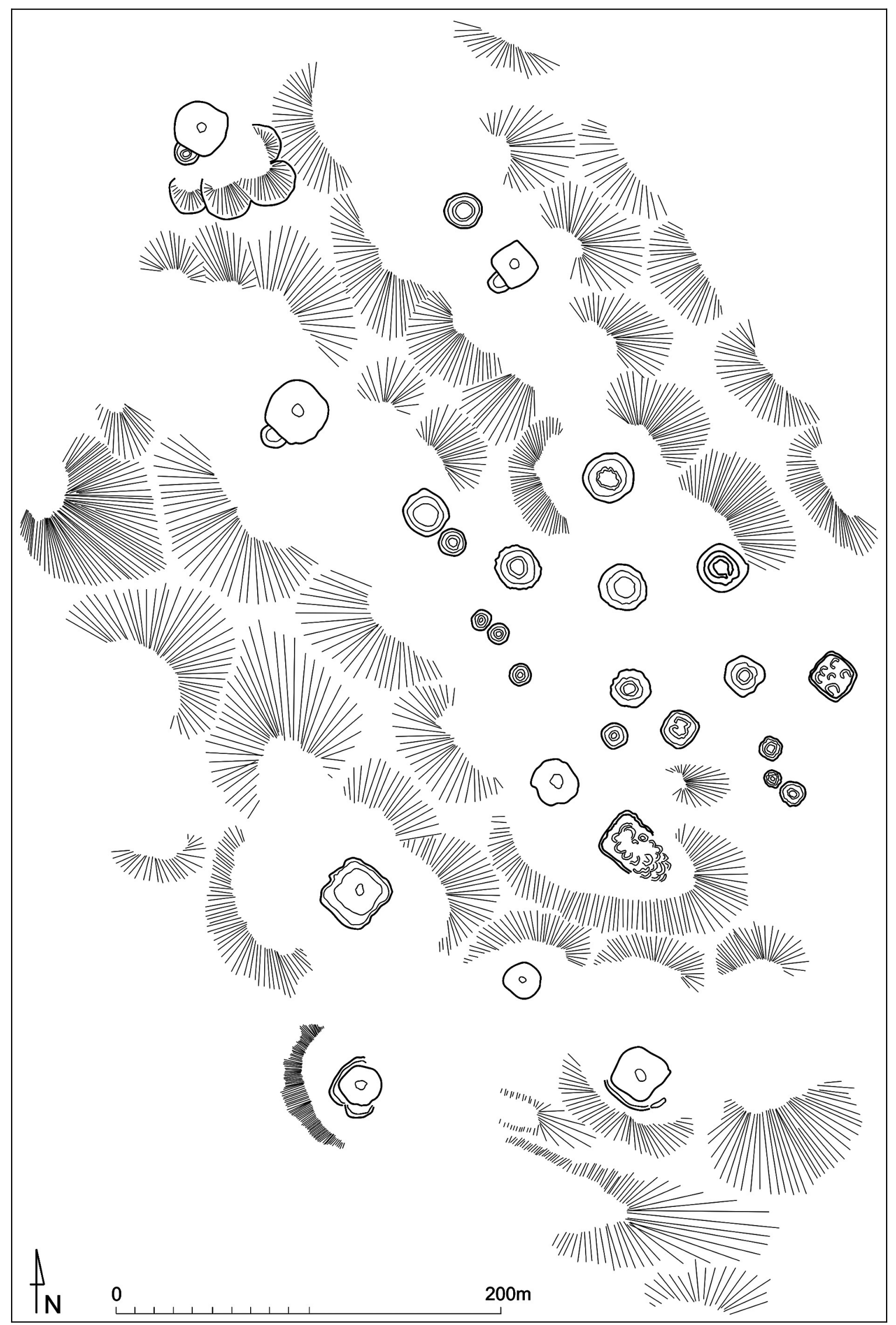

FIGURE 2.2 Redrawing of Lepsius's plan

DRAWN BY S. LENARCZYK AFTER LEPSIUS $185^{2}$ 


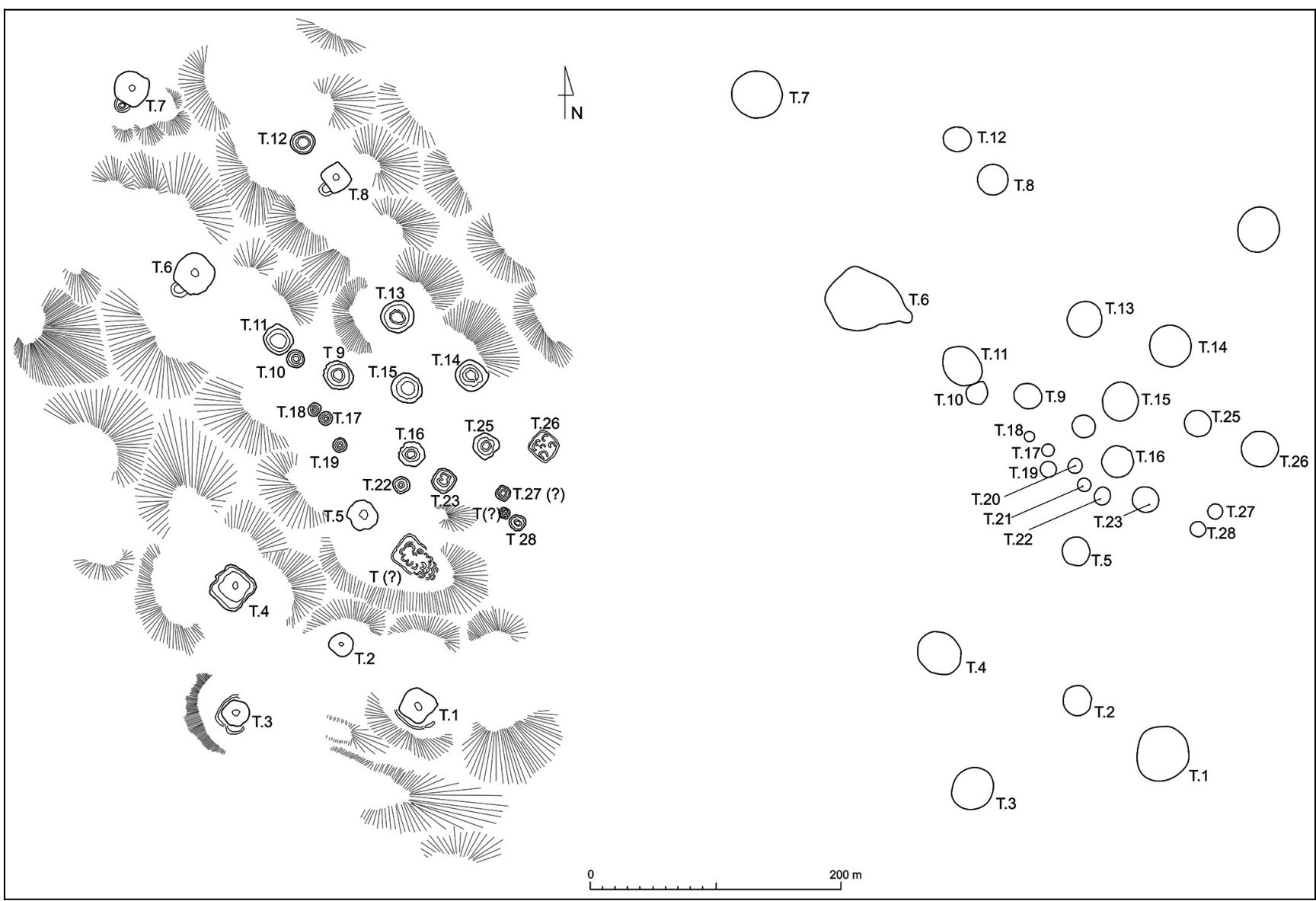

FIGURE 2.3 Comparison of plans made in the 19th (left) and 21st century (right) DRAWN BY S. LENARCZYK

edges of the tumuli may have spread further outwards as a result of rainfall or subsidence of the earth and stones from which the mounds were built [see Fig. 2.5]. Frequent robber activity has also had a detrimental effect on the state of these structures.

The differences in distance between specific tumuli is attributable to a surveying error. A comparison of the two plans suggests that the mounds on the 19th-century one are marked around 5-7 degrees further south-west in relation to their real positions.

It is also worth taking a closer look at the individual tumuli recorded on both plans. On the 19th-century plan, the outline of a narrow structure(?) is marked to the south and south-west of T.1 and T.3. These 'structures' appear to surround the tumuli. There is no record of their height or function, and we do not know whether they were integral parts of the tombs or simply built to protect the mounds from being buried by sand. In the case of T.26 and T(?), lines denoting similar 'structures' are shown encircling each tumulus on the 19th-century plan. No trace of any such structure around any of the tumuli can be found today [Table 2.1].
Analysis of Lepsius's plan revealed significant details about T.6, T.7, and T.8. Features marked alongside these mounds proved to be the external shafts that led directly to the burial access tunnels. Their existence was confirmed by modern-day excavation. Interpreting the evidence provided by this 150 -year-old map helped identify the location of these external shafts [Fig. 2.4].

Travellers who visited El-Zuma in the 19th century did not identify T.2O and T.21, both of which are currently visible on the ground surface.

A line of tumuli identified in the field by Lepsius (today's T.27 and T.28) appears to have been mapped at the wrong angle on his plan. Moreover, Lepsius recorded three tumuli of small diameter, whereas only two are currently visible. In the case of T.28 it seems almost certain that the superstructures shown on the two respective plans are one and the same; however, in the case of T.27 it seems likely that the mound recorded on the contemporary plan does not correspond to the one mapped in the 19th century.

Tumulus 30 appears on Lepsius's plan as a square structure with evident damage to its south-east side, but there 
TABLE 2.1 Comparison of base diameter measurements of the tumuli recorded by Lepsius and by the PCMA team

Tumulus Lepsius's measurements (1852) Contemporary measurements (2014-2015)

\begin{tabular}{|c|c|c|}
\hline T.1 & 34.5 om & $40.70 \mathrm{~m}$ \\
\hline T.2 & $18.95 \mathrm{~m}$ & $22.30 \mathrm{~m}$ \\
\hline $\mathrm{T} \cdot 3$ & $27.60 \mathrm{~m}$ & $32.70 \mathrm{~m}$ \\
\hline T.4 & $32.20 \mathrm{~m}$ & $34.10 \mathrm{~m}$ \\
\hline $\mathrm{T} .5$ & $24.40 \mathrm{~m}$ & $21.80 \mathrm{~m}$ \\
\hline T.6 & $32.80 \mathrm{~m}$ & c. $44 \mathrm{~m}$ \\
\hline $\mathrm{T} \cdot 7$ & $26.65 \mathrm{~m}$ & $37 \cdot 56 \mathrm{~m}$ \\
\hline T.8 & $24.05 \mathrm{~m}$ & $23.60 \mathrm{~m}$ \\
\hline T.9 & $22.80 \mathrm{~m}$ & $22.07 \mathrm{~m}$ \\
\hline T.10 & $14.10 \mathrm{~m}$ & $16.65 \mathrm{~m}$ \\
\hline T.11 & $22.60 \mathrm{~m}$ & $30.08 \mathrm{~m}$ \\
\hline T.12 & $19.60 \mathrm{~m}$ & $22.30 \mathrm{~m}$ \\
\hline $\mathrm{T} .13$ & $26.10 \mathrm{~m}$ & $27 \cdot 31 \mathrm{~m}$ \\
\hline $\mathrm{T} .14$ & $25.70 \mathrm{~m}$ & $31.50 \mathrm{~m}$ \\
\hline $\mathrm{T} .15$ & $24.75 \mathrm{~m}$ & $28.48 \mathrm{~m}$ \\
\hline T.16 & $18.05 \mathrm{~m}$ & $18.25 \mathrm{~m}$ \\
\hline T.17 & $10.75 \mathrm{~m}$ & $9.98 \mathrm{~m}$ \\
\hline T.18 & $10.10 \mathrm{~m}$ & $8.10 \mathrm{~m}$ \\
\hline T.19 & $11.10 \mathrm{~m}$ & $12.54 \mathrm{~m}$ \\
\hline T.20 & not recorded & $11.20 \mathrm{~m}$ \\
\hline $\mathrm{T} .21$ & not recorded & $10.55 \mathrm{~m}$ \\
\hline $\mathrm{T} .22$ & $13.44 \mathrm{~m}$ & $13.05 \mathrm{~m}$ \\
\hline $\mathrm{T} .23$ & $19.50 \mathrm{~m}$ & $20.70 \mathrm{~m}$ \\
\hline T.24 & $20.35 \mathrm{~m}$ & $25.25 \mathrm{~m}$ \\
\hline T.25 & $20.80 \mathrm{~m}$ & $21.05 \mathrm{~m}$ \\
\hline T.26 & $23.95 \mathrm{~m}$ & $29.60 \mathrm{~m}$ \\
\hline T.27 & 11.6 o m(?) & $11.63 \mathrm{~m}$ \\
\hline T.28 & $13.10 \mathrm{~m}$ & $12.40 \mathrm{~m}$ \\
\hline $\mathrm{T} .29$ & $27 \cdot 70 \mathrm{~m}$ & not recorded \\
\hline T.3o & $8.85 \mathrm{~m}$ & not recorded \\
\hline
\end{tabular}

\section{S. LENARCZYK}

is currently no evidence of it in the field. The same is true of T.29, a small tumulus marked on Lepsius's map. We can assume that this mound has been destroyed during the course of the past 150 years.

Further notes and sketches concerning El-Zuma were made by Budge (1907, vol. I, 127, 129, 170; vol. II, 116; 1912, 866-867) and Wilkinson (Żurawski 2003, 382), and Reisner $(1918,67)$ also mentioned this site.

Archaeological research in El-Zuma was accompanied by interviews with the local community about craft and building traditions as well as about the settlement itself. According to locals, the name El-Zuma means a bend of the Nile (oral information).
Within the last few decades, the village settlement has significantly changed its location, moving further to the north-west and north-east. This was prompted by two factors:

1. The construction of a new asphalt road (from Karima to Wadi Nawa), running north of the village. Before this, the main road (which was the transport route along which settlements were concentrated) ran along the Nile, at the southern borders of the village. Relocating the road made the centre of village life move to the north-west part of the settlement.

2. The flood in 1946 (Żurawski 2003, 382), which caused destruction in the southern part of the village and 


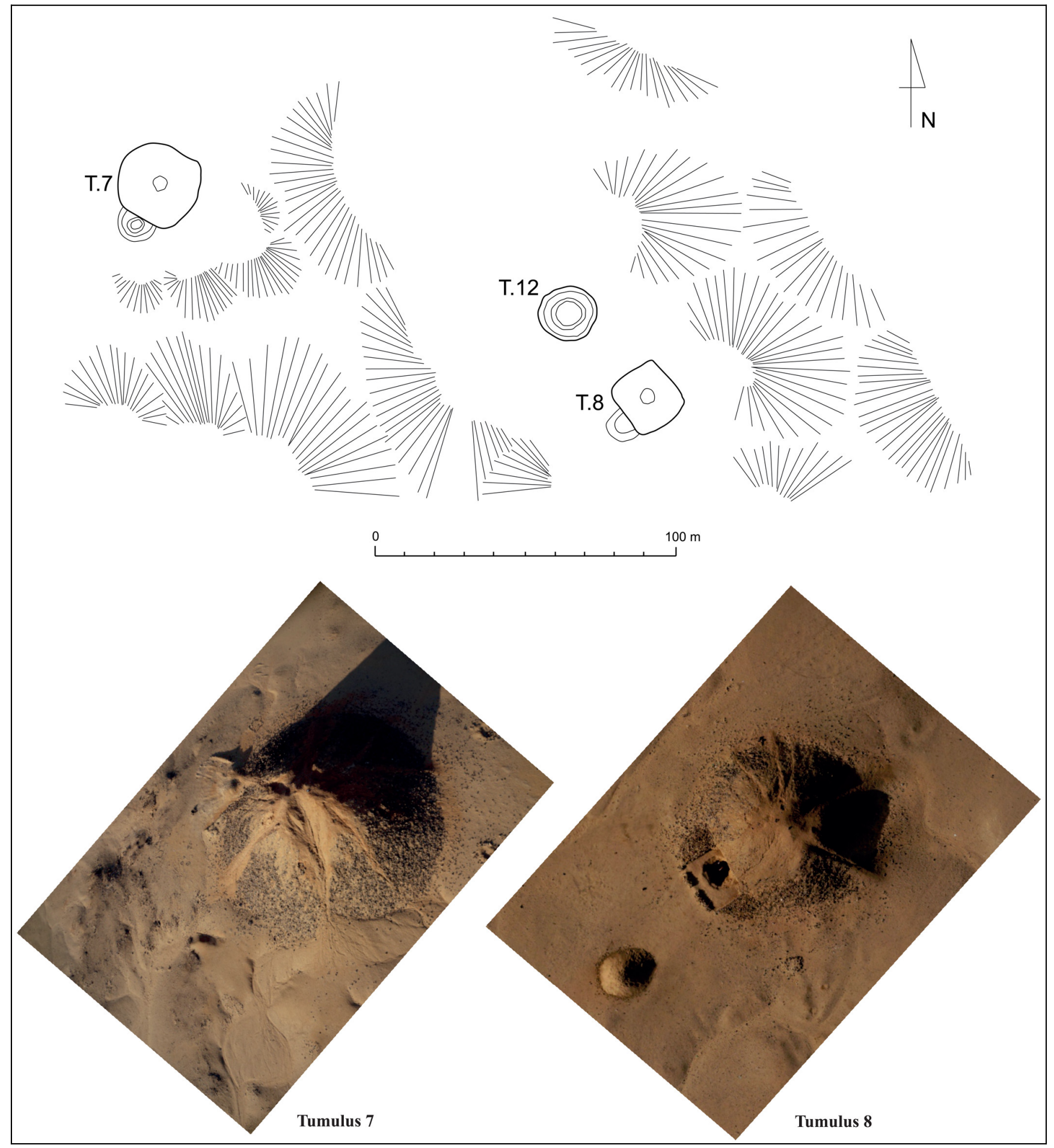

FIGURE 2.4 Comparison of tumuli featuring external structures(?) recorded on Lepsius's plan with the same tumuli as seen during excavations in 2014/15

PHOTOS BY A. KAMROWSKI, DRAWN BY S. LENARCZYK 


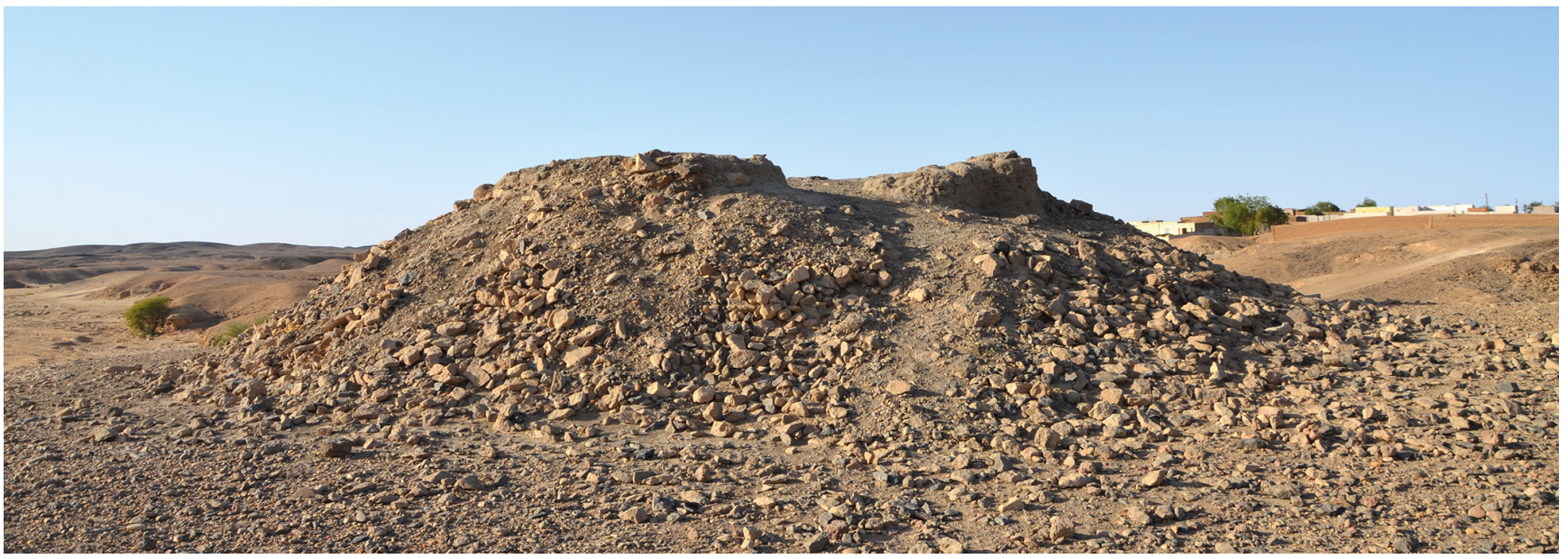

FIGURE 2.5 The site of Ali El-Karar in 2016 PHOTO BY Z. KOWARSKA

made many families move to higher-lying areas in the northern part of the settlement.

Unfortunately, in interviews with the oldest members of the local community, it turned out that their memories stretched back only 20-30 years, which significantly impeded the collection of additional information.

There are also some archival photographs taken in ElZuma village during Breasted's expedition at the beginning of the 2oth century (https://oi.uchicago.edu/gallery/ zuma\#II7F11_72dpi.png).

\section{Archaeological Survey}

One of the first points of fieldwork was conducting an archaeological survey to find and record any traces of the past visible on the surface. These operations were run based on the prior desk-based assessment of historical sources, texts, maps, and photographs taken from the air. The site had previously been examined during the Sudanese-Italian Magashi-Barkal survey in 1992, led by Irena Liverani Vincentelli (Żurawski 2003, 90). Further surveys were performed by Bogdan Żurawski within the SDRs project (Southern Dongola Reach Survey), held during 1997-2002. Fieldwork carried out between 2000 and 2002 led to the identification of five archaeological sites (Żurawski 2002, 73-75, 84; 2003, 90-91, 95):

- Ez-Zuma 1 - a round structure with a diameter of about 4-6 $\mathrm{m}$, of unknown origin and date, known as Ali ElKarar in the local oral tradition [Fig. 2.5];

- Ez-Zuma 2, the so-called "Anchorite Grotto" - a chamber carved into the rock below Ali El-Karar, dated to the Pharaonic or Kushite period (Żurawski 2002, 84; 2003,
379, Figs. 10-11; cf. Monneret de Villard 1935-1957). The inscriptions from the 'cave' were documented during the SDRS project (Łajtar 2003, 512-517). The cave of Ali El-Karar is situated in a wadi [Fig. 2.6];

- Ez-Zuma 3-a tumulus cemetery; pottery found on the surface was dated to the early Christian period;

- Ez-Zuma 3a-according to Żurawski, the likely location of the "fortress" seen in 1844 by Lepsius (Żurawski 2003, 382, Fig. 8);

- Ez-Zuma 4-a destroyed and looted cemetery dating from Early Dongola to the present, located close to the road along the Nile, in the direction of El-Detti.

In the first season of the Early Makuria Research Project, an area within a radius of about $1 \mathrm{~km}$ of the tumuli was divided into smaller sections and a more detailed fieldwalking survey was conducted (Obłuski 2005). Based on the results of this work it was possible to define the extent of the El-Zuma site.

\section{Topographical Work}

Topographical work ${ }^{1}$ was divided into phases:

1. Creating complete geodetic maps of the site (vector maps, contour maps, $3 \mathrm{D}$ visualizations of each tumulus, and of the site topography).

2. Recording grave substructures excavated over a number of research seasons. Drawing up plans and crosssections of all tunnels and tumulus chambers in

1 Measurement and photographic documentation during this period was prepared by: Szymon Lenarczyk, Zofia Kowarska, Jolanta Juchniewicz and Adam Kamrowski in 2014; Lenarczyk, Kowarska and Kamrowski in 2015; and by Magdalena Antos and Kamrowski in 2017. 


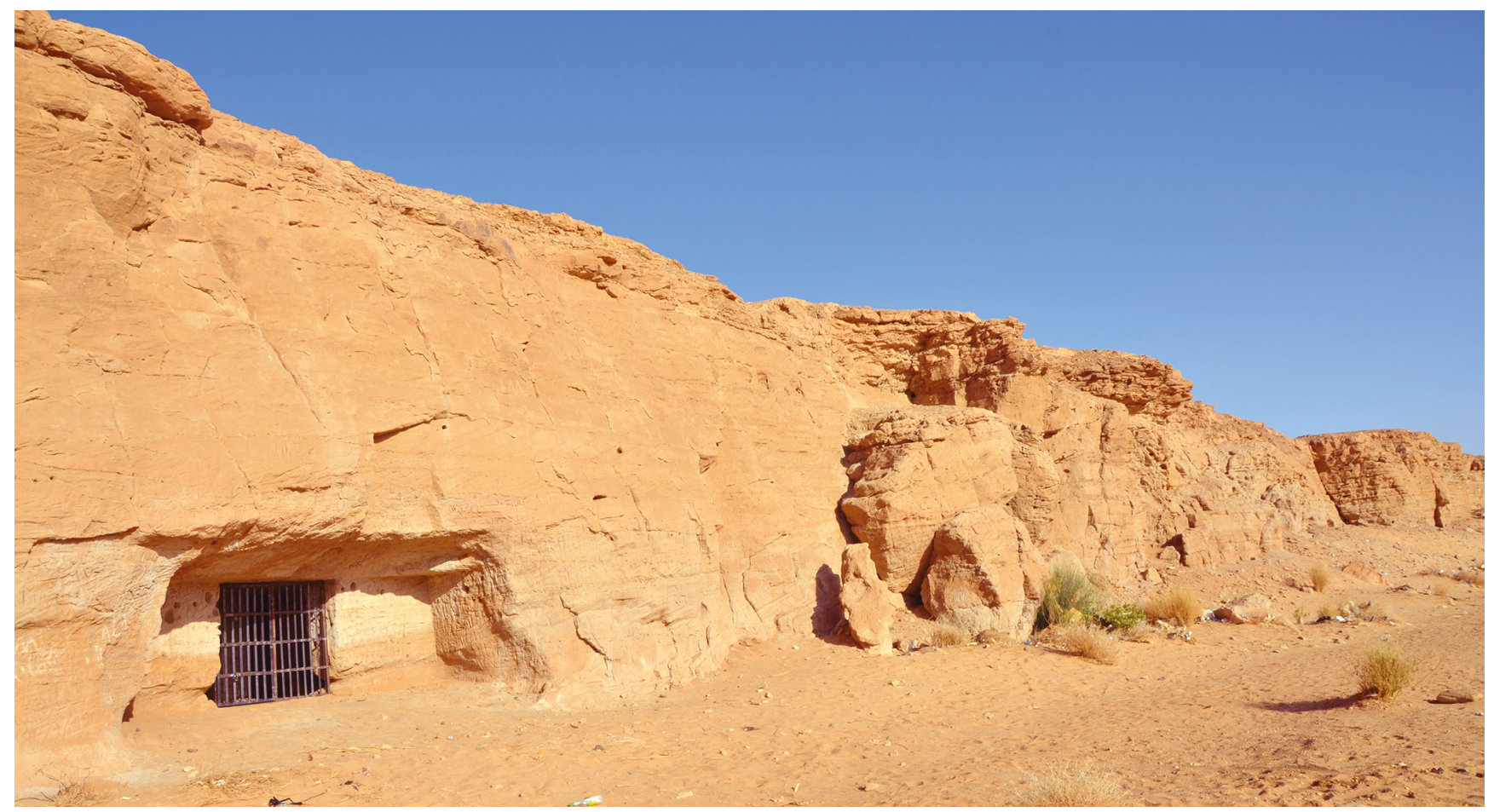

FIGURE 2.6 The so-called "Anchorite Grotto," Ali El-Karar, 2016 PHOTO BY Z. KOWARSKA

AutoCAD and Corel. Some walls and cross-sections together with soil layers were additionally documented using photogrammetry. Based on photographs, a partial $3 \mathrm{D}$ model was made in Agisoft and ${ }_{3}$ D Max. The biggest problem was taking measurements and photographs inside the tunnels leading to the tumulus chambers. Narrow and low spaces impeded the setting up of equipment, and internal structural divisions (partition walls, pillars) made it necessary to move the equipment from place to place multiple times. Photographic recording was also hampered to a large extent by insufficient lighting and by not being able to move far enough away from the photographed area. Low levels of oxygen, high temperatures, and dust clouds, especially in the farthest parts of the tunnels, resulted in frequent interruptions to the tasks at hand.

3. Installation of a perimeter fence around the tumulus field and demarcation of a buffer zone. ${ }^{2}$ Until recently the site had been used by the inhabitants of El-Zuma village as a shortcut to the main road, which was destroying the remains of archaeological features. The fence has prevented cars from enter-

2 Work on the perimeter fence, designed by Jolanta Juchniewicz, started in 2014. ing the cemetery area, and has limited the encroachment of the village of El-Zuma onto the archaeological site.

4. Schematic architectural documentation of the outline of the street grid and buildings of the modern village. The archaeological site was marked on a present-day map of the dynamically growing village. To achieve these aims, a series of closely related fieldwork tasks was undertaken. The effect was the creation of precise orthophotos, vector maps and raster maps of the whole area, as well as aerial photographs correlated with contour measurements and visualizations of selected tumuli.

The success of the actions taken depended not only on selecting an appropriate methodology for the site but also on weather conditions. Thus, a wide variety of topographical recording methods, adapted to the specificity of the area being examined, was used (Bogacki 2015).

\subsection{Topographical Survey of El-Zuma Site}

The documentation and inventory of ancient structures was divided into two stages: a geodetic survey performed on the site, and graphic presentation of the data retrieved in the field. A Leica FlexLine TSO2 Total Station plus $\mathrm{R}_{5} \mathrm{OO}$ EDM was used for geodetic measurements, together with a handheld Garmin GPS device. A local site grid was set up. Detailed raster maps of the excavated area and a $3 \mathrm{D}$ 

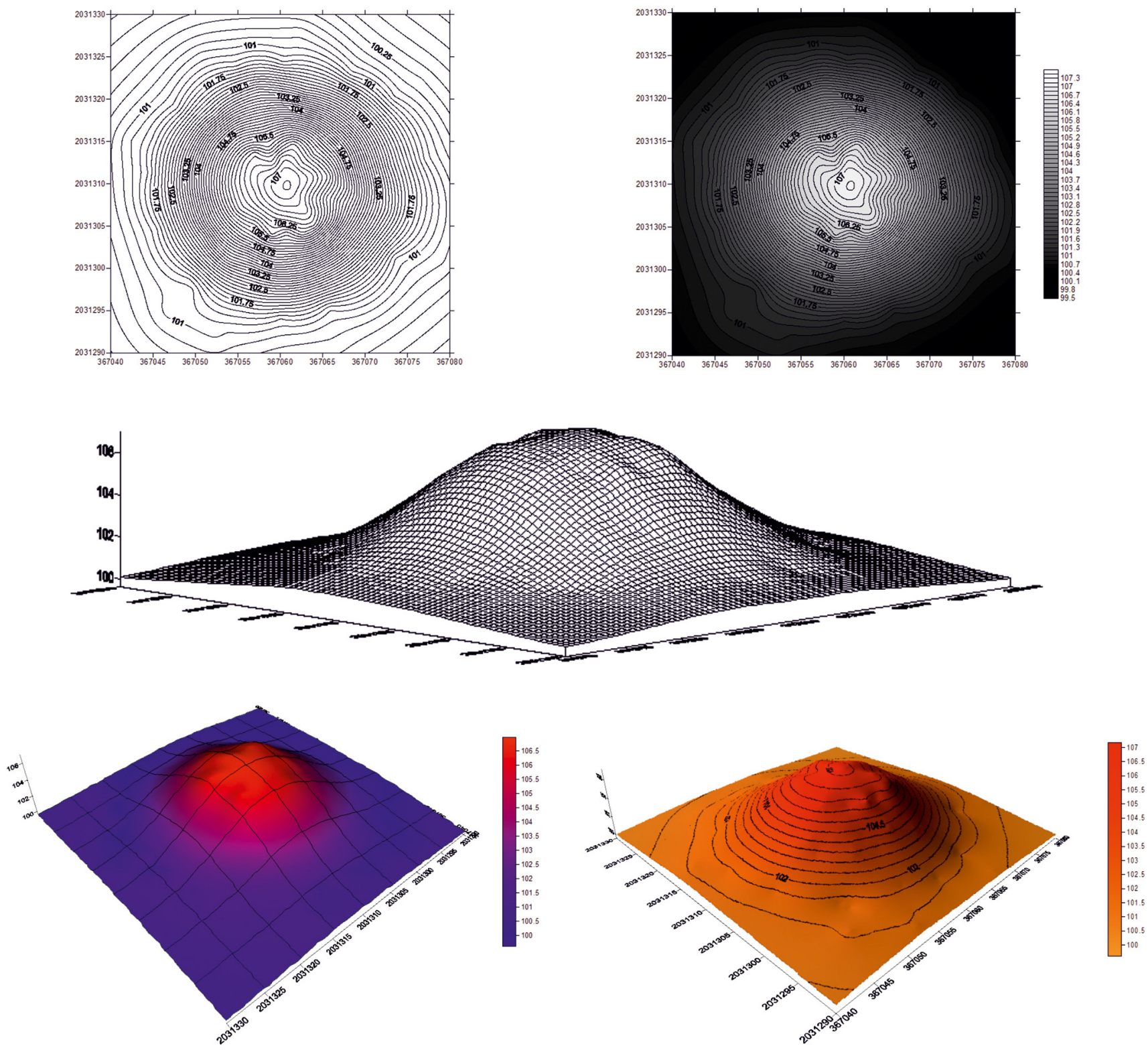

FIGURE 2.7 Example of documentation of one of the tumuli PRODUCED BY Z. KOWARSKA, S. LENARCZYK

contour map of the area were produced from the measurements taken on site.

Twenty-eight tumuli were plotted on topographical maps. A separate survey was made of each tumulus, the level of detail recorded depending on its characteristics and state of preservation. All structures were measured from base to top, and N-S and E-W cross-section drawings were prepared which enabled the height, volume, and extent of the mounds to be calculated [Fig. 2.7].

\subsection{Kite Aerial Photography}

A significant part of the topographical work was based on images taken from various altitudes above the site. Aerial photographs facilitated the analysis of the researched area and made it possible to discern the remains of ancient constructions invisible from the ground.

The first aerial photos of the surroundings of El-Zuma were taken in the 1930s by RAF pilots (Żurawski 2002, 84; 2003, 380-381, Figs. 13-14). The next pictures were taken from a small aircraft at the beginning of the 199os, and although these images cannot be described as documentary material, they do provide evidence of the gradual degradation of the tumuli. A series of kite aerial photographs documenting the site was taken in February 2002 during the Southern Dongola Reach Survey project (Żurawski 2003, 381, Fig. 15). Another series of kite photographs of the El-Zuma area was taken in February 2012 by Miron Bogacki and Wiesław Małkowski. 

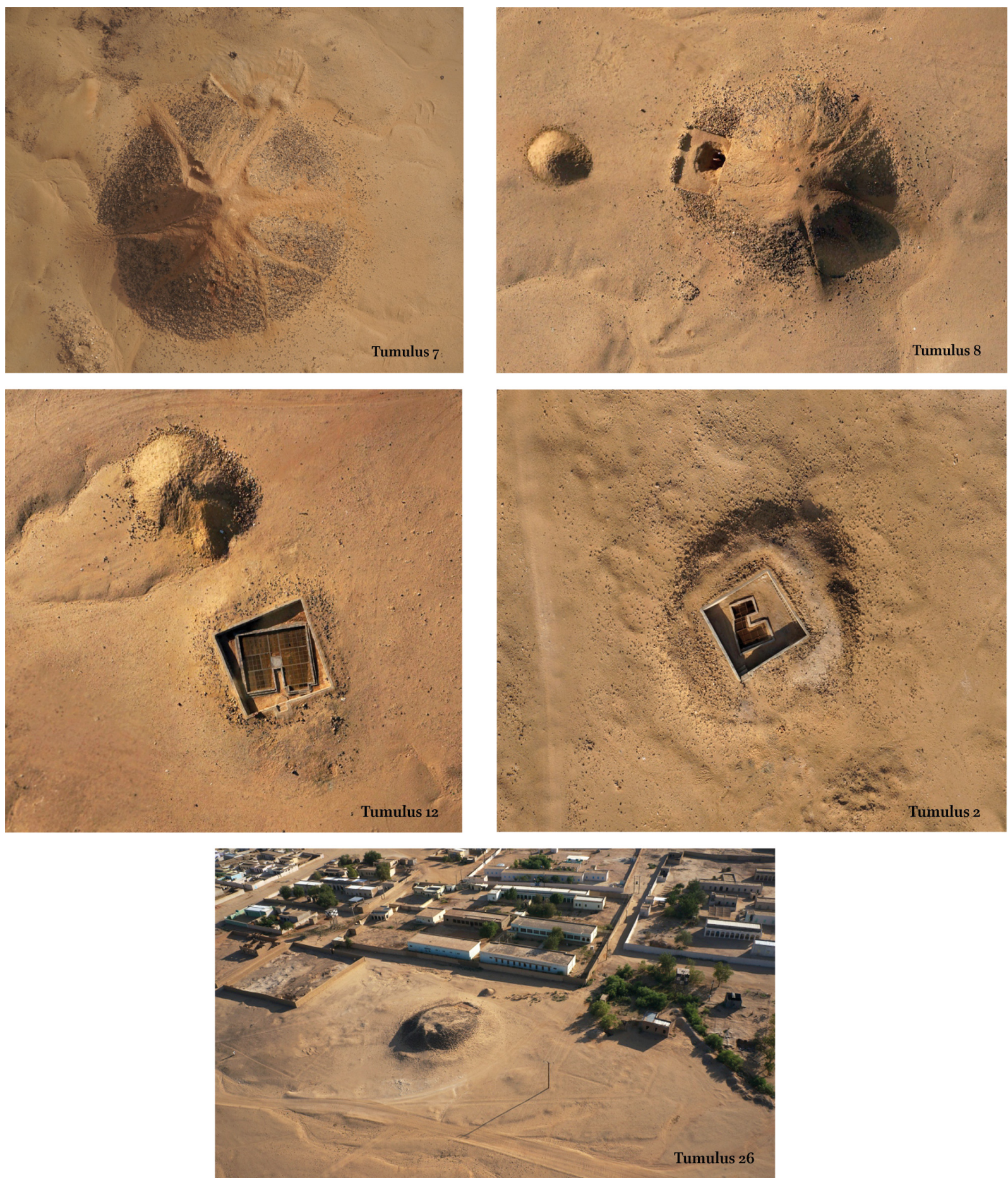

FIGURE 2.8 Examples of aerial photos of tumuli, 2014/15 PHOTOS BY A. KAMROWSKI

Comparison of archival photos with contemporary images illustrates the scale of the change and destruction to the archaeological structures caused by the expansion of the modern village.

Using a combination of different methods it was possible to compile a complete record of the site and compare current data with the archival data. A composite map was produced using all of the data acquired in the field combined with calibrated ancient maps.

During the archaeological works, Adam Kamrowski and Szymon Lenarczyk took a series of new photographs of the site from a kite. These images, taken from an appropriate height, in various lighting conditions and at different times of day, provided valuable information [Fig. 2.8]. The 
photos were taken with a remotely controlled Nikon D 600 camera mounted on a WoBie's KAP'n'Hook rig, suspended from a Didakite Explorer kite. The process of taking photos and the quality of the images depended on many factors, such as the time of day and sunlight levels, therefore the photographic sessions were repeated multiple times.

The use of kite aerial photography in El-Zuma was a complicated process because of weather conditions. Strong, predominantly northerly, winds at specific times of the day-between 10a.m. and 12 p.m. and 4-6 p.m., when the sunlight is optimal for photographic documentation-dictated extremely precise timeframes for taking pictures during the day. Windborne sand made it necessary to change the working hours to avoid damage to the lens or the camera. Conversely, a too-weak afternoon wind was not able to carry the kite $\left(7-9 \mathrm{~m}^{2}\right.$ surface area). High temperatures also determined the timeframes of individual sessions. As all of the archaeological missions took place between January and March, it was not possible to conduct kite sessions during different seasons of the year. Another problem was the electric grid in the village of El-Zuma. The proximity of high-voltage posts and cables significantly limited the ability of the kite to reach the required altitude of several hundred meters above the ground surface.

Tens of so-called photo-points were defined and documented during the recording of individual tumuli to prepare further field documentation (aerial photographs). Traditional photography was used to record the details which could not be captured by kite photography.

\section{Results}

The combination of different methods discussed above enabled the creation of an orthophoto map of the whole archaeological site [Fig. 2.9]. Based on the maps and descriptions found in 19th-century written sources, and on aerial photos from the 2oth and 21st centuries, as well as precise topographical measurements, full field documentation of the El-Zuma site could be prepared. ${ }^{3}$

A series of perpendicular kite photos, a contour map, raster maps, a $3 \mathrm{D}$ model of the site and of individual tumuli, made it possible to create a partial three-dimensional visualization of the surrounding areas of the

3 The software used for graphic processing of the collected data is: AutoCAD (for initial processing of data retrieved in the field), Corel DRAW $\mathrm{X}_{5}$ (for graphic and aesthetic data digitization), AgiSoft, $3 \mathrm{D}$ Max and Zephyr Aerial ${ }_{3} \mathrm{D}$ or Unity (for creating ${ }_{3} \mathrm{D}$ models and for photogrammetric operations), Surfer (for developing a contour area profile). archaeological site and the tumuli. All of the data from this fieldwork has been collated in a database to which fresh information obtained using new surveying techniques can be added. 


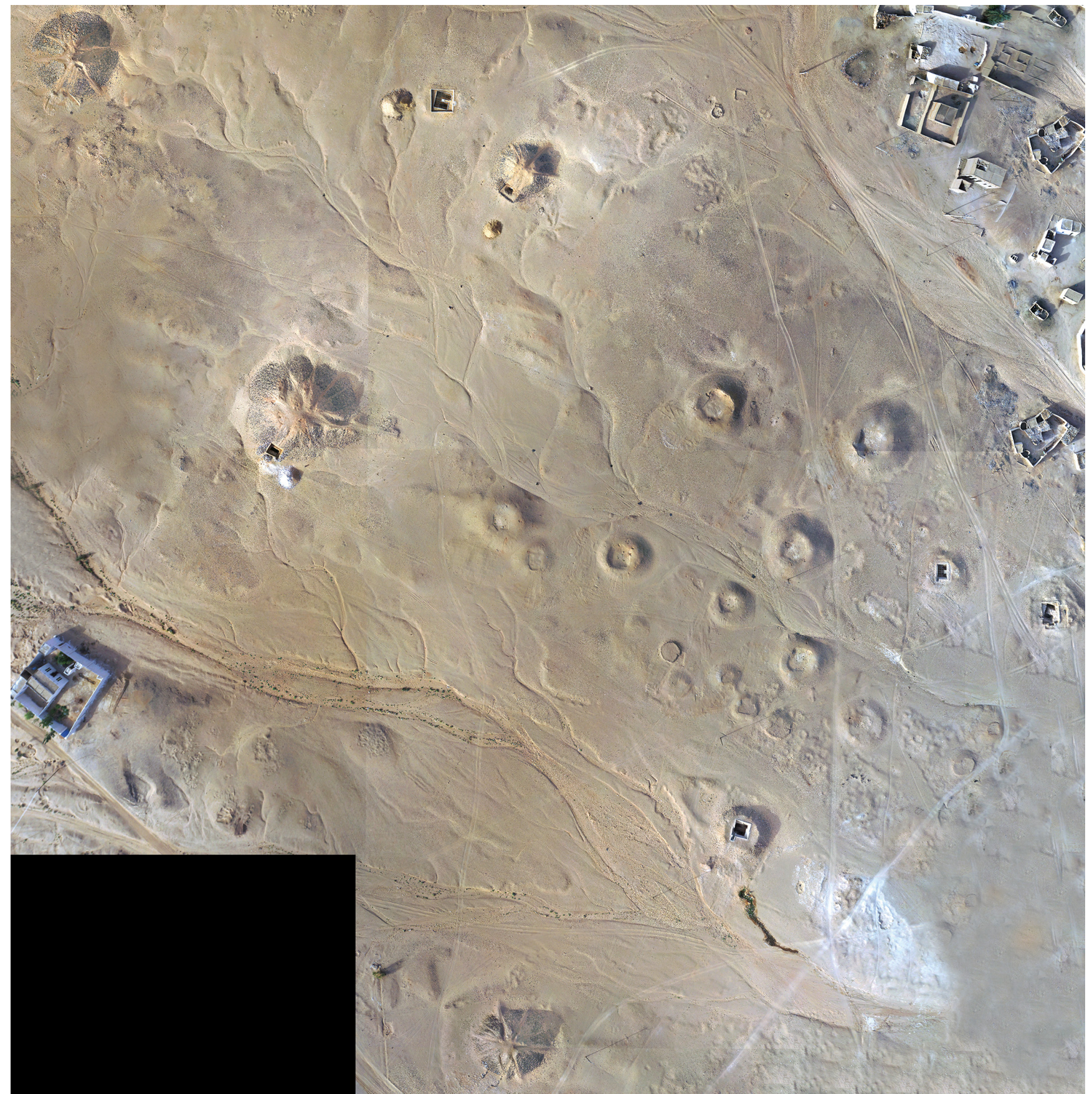

FIGURE 2.9A Orthophoto map of archaeological site at El-Zuma, 2014/15 PRODUCED BY A. KAMROWSKI, S. LENARCZYK 


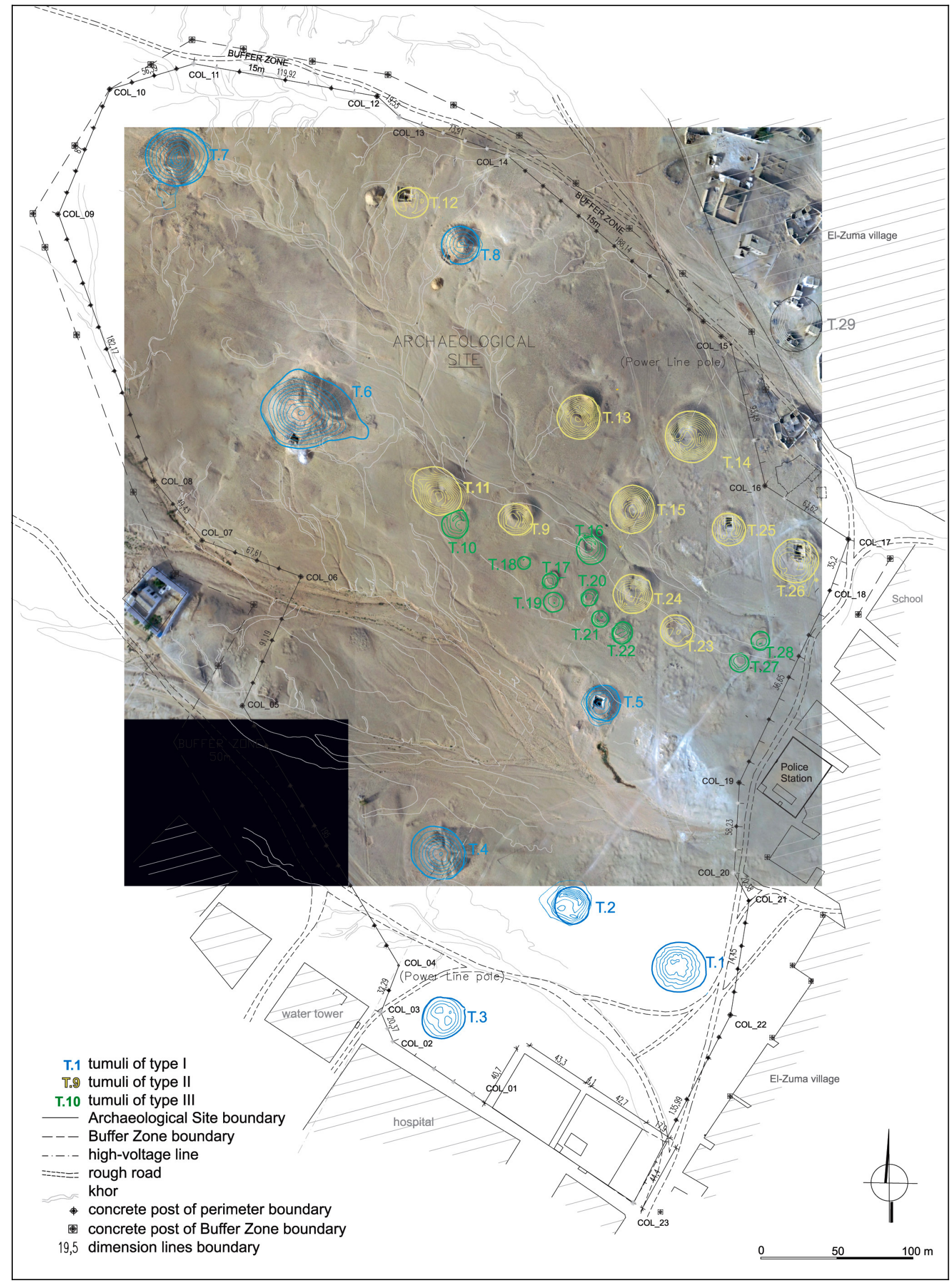

FIGURE 2.9B Orthophoto map of archaeological site at El-Zuma, 2014/15, with superimposed site plan PRODUCED BY A. KAMROWSKI, S. LENARCZYK 